\title{
Rijkuo-Maja and Silbo-Gåmmoe- towards the Question of Female Shamanism in the Saami Area
}

\author{
BY BO LUNDMARK
}

\section{Rijkuo-Maja-female noaidie of the forest Saamis?}

Among the forest Saamis of Arvidsjaur the traditions about Rijkuo-Maja are still alive. She was married to Nils Hindersson, who died before 1730. She herself died in 1757 at the age of ninety-six years old (AKB Nyman \& Nyman 1973, 3). The year of her birth must therefore have been about 1660 .

When Edvin Brännström, at the beginning of the 1930's, was collecting traditions about Rijkuo-Maja on behalf of Dialekt- och folkminnesarkivet $i$ Uppsala, he realized that descent from her was regarded as something very prestigious (ULMA 5585, 46). Her main home was by Mausjaur, called Lundby. In 1730 she paid three dalers in silver coins for the Lapp fiscal area of Mausjaur. Eleven years later she was registered for 2,16 dalers.

She acquired her nickname because of an unusually large reindeer herd. "Wealthy, rich" is "rijkkuo" in the Arvidsjaur Saami dialect. The corresponding term in the neighbouring Malå dialect is "riikhoo". Other words with the same meaning in these dialects are "adnèja" and "bàndàs" (Schlachter 1958, 3, 20, 110).

When a Saami woman in the area wanted to show how wealthy she was, she often did this by wearing several frocks on top of each other, so that the shortest would be on the outside, the second shortest next and soon. Rijkuo-Maja apparently wore five (ULMA 5585, 46)!

The general belief was that her wealth depended on the fact that she was master of the noaidie's arts. Thus, for example, she is said to have had only one shepherd in spite of the size of her reindeer herd. There are many traditions according to which she "knew" her reindeer in a special way. On one occasion her godson Vuolla was to receive a reindeer as a gift. He came skiing to Rijkuo-Maja's home to fetch the reindeer, but only the servant girls were at home. Rijkuo-Maja herself was out milking some reindeer cows. At that time it was the custom to milk even when the snow had come. Vuolla skied on, and finally found her. It was foggy and the reindeer were so numerous that they "were crawling like ants whichever way you looked', as it is expressed in a written record. Nevertheless, she pointed 
out a particular reindeer cow far away in the birch forest, and said: "My godson, there's your reindeer cow!' (ULMA 4373 a, 53).

The people in Rijkuo's neighbourhood had to comply with what she had decided, even the menfolk. They were thus forbidden to engage in any hunting within her area, as she had placed the wild animals and the most edible birds "under her protection". One of her brothers-in-law was apparently an outstanding hunter and once shot a bird in the forbidden area. Rijkuo-Maja then ordered that the quarry should be sacrificed on a large tree on the western slope of Tallberget. In the bark, a human face was carved (ULMA 4373a, 107).

Judging by tradition, the thunder god. Horagalles or Atjakatj, seems to have been the object of her particular devotion. According to Lars Jonsson of Mausjaur she had chosen reindeer who were marked out for the thunder. They were sacrificed on special occasions by being buried so that only the antlers stuck up above the ground, i.e. a so called tjekku-sacrifice. The sacrifices were generally made at Askmyren. If the sound of thunder was heard, this was a sign that the sacrifice had been well received.

By the above mentioned sacrificial bog she had several luovveh, platforms for the birds. There, she put out meat for the raven, the eagle and the koksik (in lule-Lappish guovsak), i.e. the bench jay. They seem to have helped her. An informant reports that even the wolf was in her service and so she did not need any dogs. When her two daughters got married and the sons-in-law came with their dogs, she became angry. In her opinion, the dogs could be a nuisance and drive away the reindeer (ULMA 4373a, 53).

A stone-seite is connected with Rijkuo. It is situated out in Lake Mausjaur and measures almost a meter in diameter. The rock is nearly 70 centimetres above the surface of the water and is often visible, even in the winter. According to the records, it appears that there was also a sort of stone altar on the headland nearby, where sacrifices were made. According to another account: "Rijkuo-Maja and her husband made sacrifices to the rock in Mausjaur, when they went to fish; they sacrificed the sort of fish they wanted to catch" (Kolmodin 1914, 27). According to a modern informant, Rijkuo-Maja also sacrificed silver objects on the fishing rock. Thus a silver cup was found at the bottom of the lake by the stone (Lundmark 1977, 64).

Tradition also ascribes a drum to her. It is mentioned amongst other places in connection with a forest fire which broke out on Storberget. The fire threatened to destroy the fine reindeer pasture. But Rijkuo-Maja, who during the last years of her life was blind, made the servant lead her down to the lake. She also took the drum with her. Having waded out quite a long 
way, she threw a veil, lijnie, over her head. After this, she began to whistle, splash water and beat the drum. According to the informant, the thunder came in a large black cloud over Storberget. The subsequent downpour is supposed to have put out the fire quickly (ULMA $4373 \mathrm{a}, 48$ ). The fate of the drum in question is unknown.-One informant reports that she had a skudnjaa over her head, a sack-like rug of the sort one slept in (FA1). One tradition claims that while she was whistling, she struck the water three times with her stick with brass trimmings (Ramselius 1920, 54).

Before Rijkuo-Maja ended her days, she expressed a wish to be buried on Storberget. Then she would be able to hear the clattering of the hooves when the reindeer were nearby and the sound of oars from Lake Mausjaur. She also warned her family about not following her will, which would result in the whole herd being destroyed. On the evening when she died, she seems to have been sitting among her reindeer in the pasture (Manker 1939, 166). One of the sons-in-law thought that the suggested method of burial seemed too heathen, and so Rijkuo-Maja was buried in the churchyard in the conventional manner. According to what is related, this was followed by bad reindeer years and the herd made its way down towards the coast. The reindeer were impossible to stop! The men had to run after them and stab them with spears; but, in spite of this, the majority of them drifted out to sea on ice-floes by what is now Rönnskär. Soon Rijkuo-Majas reindeer herd was just a memory (ULMA 4373a, 49; NM 573, 638, 641)!

But "the mountain where she wanted to lie after her death we still call Akkanålke" according to her present-day descendant, Maria Jonson of Mausjaur (ULMA 4373 a, 49). She also reports that Nils Henrik Stenvall in Mausjaur later became owner of the "thunder mark" (NM 1032).

The local historian Beda Wiklund from Bureå had some interesting information in her posthumous papers about the dramatic final stage. She assumes that it was Rijkuo-Maja's reindeer herd which drifted out to sea between Burvik and Rönnskär, "an event which my father said his own grandmother had described to him when she was a child". This actually emphasizes the great dangers in travelling over the sea. The example is given of a reindeer herd consisting of thousands of animals which drifted to sea some years ago. "It was claimed that fishing for Baltic herring was particularly rewarding for a few years afterwards, which was said to be because the sea was giving something in return." Wiklund also believes that Rönnskär (Rowan skerry) is a corruption of the original Renskär (Reindeer skerry). The Mausjaur Saamis had, since ancient times, a natural crossing here on the Skellefte river for their reindeer. She also finds support 
in the dialect for her interpretation: "The plural form for renar (reindeer) and rönnar (rowan trees) is pronounced identically: rääina" (FA 2).

\section{Silbo-gåmmoe-female noaidie of the mountain Saamis?}

We find the next female figure of interest to our discussion among the mountain Saamis of Tärna. She was called Anna Greta Matsdotter and came from Vapsten, being better known by the name of Silbo-gåmmoe or Gammel-Silba. She was born in 1794 and died in 1870 (Egerbladh 1969, 51). She thus represents a considerably later period in time.

Traditions about her are not so numerous as those concerning her fellow Saami in Mausjaur. Nevertheless, the nickname is interesting. The first element should be equated with silbe, silver. Gämmoe actually means "wife". The epithet is meant to have arisen because her drum was richly decorated with silver objects! There is no information about how she acquired the drum or about who made it. It seems most likely that it was inherited from her father, Mats Nilsson Druri of Lövfjäll, also called Mahti Druri or Trore (ULMA 385).

$\mathrm{He}$ is mentioned in the literature. Thus Kristoffer Sjulsson reports that Druri always had "the magic drum in the front sleigh (ackja) and conveniently to hand, so that at short intervals he could beat it and obtain council in everything' (Pettersson 1979, 77). On this point, Gustaf Hallström, and later Louise Bäckman, has pointed out that according to the sources for Saami pre-christian religion the drum was always carried in the last sleigh. "This was so that nothing unclean would cross the path of the magic drum" (Hallström 1910, 36; Pettersson 1979, 301).

According to one tradition, Druri could, with the help of the drum get the reindeer to come to the enclosure or the pasture. They apparently came "running to the enclosure with their tongues hanging out, tame and subdued"' (Forsslund 1914, 123).

Maria Sjulsdotter reported in 1909 that Gammel-Silba was "famous for magic and could also use the drum". The same informant also stated that a drum which had belonged to the Njajta family was now to be found "at Skansen" (Hallström 1910, 37). At Nordiska Museet, however, no such drum is known. The information is based on the fact that Silbo-gåmmoe married Nils Ersson Njajta (1794-1856). According to information from Maria Klementsson of Aitelnas Silba's husband also owned and used the drum (NM 1032).

Isak Rydberg has stated that Silba's drum was furnished with rings. Her father, in his adolescence, had also seen with his own eyes how Silba lay in her hut with foam at her mouth and the drum beside her. Also according to 
Ernst Manker's informant, she could "fall into a faint" (DAUM Gr. 390 B; Manker 1957, 245).

So much for her gievrie, as the drum is called in Southern Lappish. Brita Maja Nilsson of Grundträsk has also reported that a reindeer pasture was named after her, i.e. Silbo-giedtie. The same informant has also described a meeting with Gammel-Silba in her youth. According to the record: "Tsilpogummo was also a noaidie. The last time I met her was up by the Milk brook. The old woman was herding the reindeer and had no food. She was rich, but it could always happen that you found yourself without food in the reindeer-forest. I gave her a bit of meat which she put in her bosom, like they used to before and she said: Velges biena dovden goatsot-a white dog will go before you all the time. I don't know what she meant by that but a white dog must anyway be more suitable than a black one" (NM 1032). Of Silba's many sons, Nila (born 1822) became known as "the last noaidie" in Lycksele lappmark. Generally speaking, heredity on the mother's side was considered to have been decisive for him. Before Christmas in the winter of 1848 he became involved in a fight which ended in the death of his antagonist. According to one version of the fateful event, Sven Sjulsson accused Nila of having-together with his mother- "bewitched" his wife to death. For having killed Sven Sjulsson without the excuse of self-defence Nila was sentenced to death by Lycksele district court. The Court of Appeal (Svea Hovrätt) nevertheless commuted the sentence to two years hard labour on Långholmen. Stor-Nila or Spå-Nila, as he was generally called died, together with his wife in a snowstorm by Oxtinderne in 1899 (TFA Död- och begravningsbok 1899).

There is no reliable evidence to suggest that Nila inherited and used the drum. He is, however, said to have inherited the scarf of squirrel tails from his mother. This was an invariable accessory at Nila's seances. One informant reports that once while at church Nila put the scarf in his belt and let one end drag on the floor. "This was also a sign that he intended to practise divination" (ULMA 5585, 64).

\section{Lapp-Stina and Spå-Ella-two more examples}

In his Fragmenter i Lappska Mythologien Lars Levi Laestadius has much to say about Lapp-Stina, whose abilities were particularly evident in the field of medicine. She was apparently a so-called parish Lapp, a native of Ångermanland (cf. Svanberg 1981, 48).

The Karesuando pastor was astonished that "an uneducated old Lapp woman, without preparatory medical studies, could have obtained such a 
deep insight into the human organism, and even more remarkable, that she claims to have learned these arts from a woman of the underworld, to whom she says she has a special relationship, that is exactly the same relationship as is reported for the real noaidies".

Stina reported that the woman from the underworld had been godparent at her christening. The account continues: "Sometimes when she is called in for more serious cases of sickness, she is in the habit of closing her eyes and reflecting a second as if to obtain information from within on the type of illness and the remedy for it. And when one asks her why she does this, she answers: I am asking my godmother."

Among the cases mentioned by Laestadius, one is struck by that of Pastor Nordenson, who had become completely blind. The latter visited Lapp-Stina and, within the course of a few weeks, had his sight fully restored. In response to those around him who asked how this could have happened he is said to have answered by quoting the words from the Bible: "One thing I know, before that, whereas I was blind, now I see."

Laestadius's comments on a case in Härnösand are also interesting. This concerned the curing of a girl who was affected with rickets. "But since, in addition to medicines, she also used some minor magic arts (probably Sympathi courses), I therefore regard it as not worth compromising persons who wish to be regarded as above all superstition, although I myself in this case do not suffer the least over their reliability; for the young girl, who no doctor had been able to cure, was truly cured by Lapp-Stina. I have been assured of this by the honourable members of the household and by the cured person herself' (Laestadius 1959, 96f.).

Judging by O. P. Pettersson's and Nils Eriksson's notes on Spå-Ella, her activities were not of a particularly redeeming kind. She seems, like SilboGåmmoe, to have sprung from noiadie stock. Her father, who had his home near Kronakken, was regarded as being "a Lapp potent in magic". According to Pettersson he was "the only one in the neighbourhood who possessed the art of making magic drums. For such a drum he demanded a price of no less than 60 riksdalers, an enormous sum at that time" (Pettersson 1944, 118).

One winter when his daughter Ella was down in Åsele an old peasant woman had annoyed her. Then she had cast a spell on the old woman so that her eyes began to squeeze out of their sockets. But the old woman went down on her knees and Ella relented, so she cancelled the spell. Then her eyes sank back into their sockets.

On one occasion, a settlers fodder was trampled by a reindeer-herd. He blamed Ella's husband for what had happened. When he came to obtain compensation however, Ella refused. He became angry and pulled her hair 
hard. In spite of this she offered him coffee and reindeer cheese, but added: "Now you'll get your deserts for pulling my hair!"

Immediately after this, the settler's son had a nervous breakdown. He said he saw reindeer and Saamis everywhere. And people in the area generally believed that he had been bewitched by Ella (ULMA 7017).

\section{Commentary and analysis}

In his study Sjiele. Samiska traditioner om offer Mebius comes to the following conclusion: "The traditional material about Saami sacrifices which has been reported here coincides most remarkably with the material that is about 250 years older. On almost every point in the sacrificial rituals we can see how faithfully the oral traditions of a later period reproduce the conditions of Saami culture in a previous period." But Mebius points out quite rightly that the overall picture constructed on the basis of the material "in most cases has no coverage in the reminiscences of the individual carrier of tradition. It is normally so that the individual informant has only been aware of a few fragments of the sacrificial cult" (Mebius 1972, 110).

Mebius, too, has used the notes of Torsten Kolmodin and Edvin Brännström from Pite lappmark. They were made in the years following 1910 and at the beginning of the 1930's respectively. The informants are often identical, as for example Maria Jonson of Mausjaur.

Her information about Rijkuo-Maja is quoted and discussed in several places in Mebius's study. These include the sacrifice of male reindeer to the thunder god, and are in complete agreement with what is cited in the accounts of Samuel Rhen and Carl Solander. The latter thus reports that they sacrifice to him "an ungelded reindeer ox" (Reuterskiöld 1910, 23). Even the special marking of the sacrificial animal in the ear is mentioned in the older source authors, including Isac Olsen (Kildeskrifter 1910, 12, 34). They also mention the burial of sacrificed reindeer-bulls. The sacrificial tree and the hanging up of the offering are also mentioned, for example the "boat sacrifice" at Christmas time (Högström 1747, 188f.). On the other hand, I have not been able to find in the older sources any direct equivalent for the reported sacrifice of a bird in the pine-tree in Mausjaur.

In the recorded traditions about Rijkuo-Maja, however, there are a number of things which conflict with the woman's role in the cult as represented in the older sources. According to these, the sacrificial sites were "as a rule a forbidden area for women" (Mebius 1968, 78). Henric Forbus reports among other things that "womenfolk may not come within 1/4 mile of Passevara, the holy mountain, and neither may they approach the place of sacrifice, but if they wish to make a sacrifice, this must be done 
through a man versed in the art" (Reuterskiöld 1910, 36). As Mebius reports "it was necessary to make some kind of expiatory sacrifice" if a woman broke the law in this respect (Mebius 1968, 78).

Rijkuo-Maja nonetheless appears to have been "versed" in matters of sacrifice, both with regard to the thunder god and the seite in Mausjaur, even if her husband also participated.

There is the additional information that she used the drum, this also being in conflict with the older accounts. As mentioned previously, tradition also ascribes to Silbo-gåmmoe a drum "with a ring grown by itself"' (Hallström 1910, 35). Emilie Demant-Hatt suggests incidentally that the drum seems to have disappeared later in the southern Lappmarks than in the northern ones. She writes: "Among the Torne and Karesuando Lapps the memory of the drums is only vague and unclear, whilst [...] the use of one drum or another is still remembered clearly among the Southern Lapps" (DemantHatt 1928, 53). Her study covered the years 1907-1916. Here there is apparently conflicting information about the relation of women to the drum. Thus Jon Jonasson of Hävlingen in Idre is cited as claiming that the hide of a calf from the previous year, laeihpen miesie, should be used for the drum "and that no woman was allowed to touch it" (Demant-Hatt 1928, 54). On the other hand, an informant in Storvallen, Härjedalen, born c. 1850 reported that her father's foster-mother Sara Larsson "had a magic drum with her when she moved down here to Herjedalen from the north, from Frostviken". It was kept for a long time in a shed until Sara buried it in a place "where it can't get in anyone's way" (Demant-Hatt 1928, 54).

Among the Saamis shamanism has been predominantly male, at least from what we know of it through 17th and 18th century accounts: Louise Bäckman states consistently: "[. . .] female noaidit seem to have been rare amongst the Lapps: in any case we can find little about them in the available source material" (Bäckman \& Hultkrantz 1978, 84).

There is not, however, a complete lack of information. There is thus mention of an old Saami who was summoned to the local assizes in Vadsö in 1691 for having used the magic drum. He explained that he had received his training from his mother, who was a noaidie. The drum, however, he himself had made (Kildeskrifter 1903, 72).

Furthermore, the missionary Isac Olsen states the following: "In the summer of 1714 Niels Andersson's woman, Kirsten Klemitsdotter, died; she was an evil old noaidie woman who everybody feared and had performed much evil with her magic and caused the death of many people. And many praised God that she died and she was fetched by the "noidegadzerna' at death's door, while she was still alive [...]' (Kildeskrifter 1910, 76). 
Hans Skanke also uses the term guaps for a sort of female equivalent to the noaidie. Skanke writes of one of these that she "knows how to yoik and make soothsaying". The same author also explains: "it is enough for that Sex to be admitted to the men's magic masses and noaidie gatherings, and to be taught to yoik and to yell their heathen antiphonas". No guaps, however, was apparently allowed to make sacrifices. This was reserved for the male colleague "who is well versed and experienced in sacrificial customs, who is their priest and him they call 'the sacrifice man' "' (Skanke 1945, 200).

The Åsele priest, Petrus Thurenius, uses the term Gåbeskied for witches. These were said to enjoy great prestige like the male noaidies. It is also reported that they can "harm another person, as well as affect the weather when they so wish" (Fellman 1910, 395). The missionary Isaac Olsen also writes Noide Kalcko, "an old witch", as a female noaidie (Kildeskrifter 1910, 85).

As far as Saami shamanistic terminology is concerned, Lindahl \& Öhrling write qwopes, qwopeswuot and qwopestallat as meaning "witch", "women's magic" and "to use magic" (Lindahl \& Öhrling 1780, 362f.). From the Luleå Saami area one may mention "kuopaskui"na, woman versed in magic" (Grundström 1946-54, 276). In Malå and Arvidsjaur one finds the names "guaps-gåb'dee, magic drum" and "nååides-gummoo, sorceress" (Schlachter 1958, 53, 104). Finally, in Stensele one notes "noåjdiesaakkaa Sauberin, Hexe" and in Frostviken "noåjdiegåmmaa Hexe, Weissagerin" (Hasselbrink 1981-85, 2, 1013).

To throw light on conditions in Swedish lappmark we turn to Nicolaus Lundius's account. With reference to his description of sueie Louise Bäckman writes: "In my opinion sueie covered the whole train of the noides, as in gažzek, i.e. the auxiliary and guardian spirits, which are both those who have taught the magic art and those who foster it," both those perceived teriomorphically and those perceived anthropomorphically. Lundius also characterizes the sueie as "a fellow worker or helper". Moreover, he claims that magic spirits of this kind never appear to women and far less stand at their disposal. On the other hand, they were able to practise "their magic arts through certain words, with which they could do their neighbour harm [...]. As regards the reason why the spirits will not unite with women, this is obscure, unless we are to believe that it occurs through pride and dislike of the sex, since it is subject to weaknesses of various kinds", (Bäckman 1975, 136; cf. Lundmark 1976, 53).

Rijkuo-Maja seems none the less to have had "fellow workers or helpers" at least of the teriomorphic kind. Amongst other things, the raven, the eagle and the bench jay were "protected" within her reindeer pasture. 
They also seem to have had some connection with the sacrificial tree on Tallberget. In this context it is interesting to note Eliade's observation of "a relation between the eagle and sacred trees" among a number of Siberian peoples. Not infrequently, the eagle in the myths of these peoples is said to have a direct part in the origin of shamanism. Among the Buriats it is thus sent from the gods for precisely this reason. According to a variant of this myth the eagle saw a sleeping woman under a tree "and had intercourse with her ... and the woman, after her connection with the eagle, saw spirits and herself became a shamaness" (Eliade 1964, 69).--Regarding the bench jay it may be mentioned that it even formed part of the name of another guaps in Arvidsjaur, Guoksag-gummuo. She also, incidentally, is said to have worshipped pine-trees with anthropomorphic features carved on them (Ruong 1944, $125 \mathrm{ff}$; cf. Manker 1957, 225).

Finally, two more comparisons: the linen cloth with which Rijkuo-Maja is said to have covered her head recalls Leem's information regarding women who were to be present at a noaidie seance. They are described as "beautifully got-up in their best clothes and with a linen hood on their heads, but without belts round their waists [...] (Leem 1767, 476). As far as Silba's and Stor-Nila's belt is concerned, one may cite what Thomas von Westen writes in his letter to the priests in Jämtland on March 11, 1723, to wit that they made spells with the belt: "[. . ] in addition they made soothsaying at Ax, Stielko, giergie, belted in Veertos and Idnus [...]' (Reuterskiöld 1910, 2). In Carl Solander's account it is also related that when a woman wanted to pray to "Passevare-Ollmaj, the holy men of the mountain, they hang up their belt and ask through it"' (Reuterskiöld 1910, 24).

Furthermore, the priest Henric Forbus in his letter to the king on March 291727 points out that this custom was commonest in the southern lappmarks. In his own words: "In the south a woman's belt [...] Herewith there is singing as long as the instrument is still moving" (Reuterskiöld 1910, 34).

The ability to reveal theft by divination in aquavit is also mentioned in the older sources. One of Forbius's questions to the Saamis was as follows: "Have you seen in the aquavit who has stolen?'" (Reuterskiöld 1910, 73.)

Neither Rijkuo-Maja or Silbo-gåmmoe functioned on the orders of a Saami community or sijte. Far less is there any information to the effect that they were elected or rewarded as shamanistic functionaries. From one point of view it probably illustrates a considerably advanced disintegration of Saami religion and the functions of the noaidie. They represent a stage where it was possible for woman to perform in new roles which were previously taboo to them.

From another point of view, they are possibly latter-day exponents of an even earlier, extant shamanism with female characteristics in the Saami 
area-a time when her role was comparable to her colleague among the Tschuktsches or the völva on Nordic soil!

I chose to leave the door of the Lapp tent slightly open. It was after all a female deity who ruled over baaissjoe, the holy area farthest in where the wild game was placed and where the bow and the drum were kept. Perhaps the first noaidie was a Rijkuo-Maja or Silbo-gåmmoe!

\section{Bibliography}

\section{UNPUBLISHED SOURCES AND LITERATURE}

Arvidsjaur

AKB Arvidsjaurs kommunbibliotek

Nyman, E. \& Nyman, R. 1973. Arvidsjaurs byar och nybyggare 1757-1897, Mausjaur. Stencil.

Funäsdalen

FA Författarens arkiv

1 Brännström, B. Mausjaur. Uppteckning gjord av B. Lundmark 26.8.1980.

2 Stenmark, H. 29.5.1978. Brev innehållande avskrift av B. Wiklunds efterlämnade papper.

Stockholm

NM Nordiska museet

Lapska avdelningen

638, 641 Stenberg, K. 1944. Arvidsjaur.

573 Rehnström K. "Rike-Maja”. Uppteckning gjord av K. Rehnström.

1032 Uppteckningar från Sorsele gjorda av T. Kolmodin 1915.

\section{Tärna}

TFA Tärna församlings arkiv

Död- och begravningsbok 1899.

Umeå

DAUM Dialekt-, ortnamns- och folkminnesarkivet i Umeå

Gr 390B S. Johansson, Rönnbäck, f. 1878. Inspelning gjord av A. Ivarsson 1957. Uppsala

ULMA Dialekt- och folkminnesarkivet i Uppsala

385 Några sägner, seder och bruk upptecknade efter lapparna i Åsele och Lycksele lappmark samt Härjedalen av T. Tomasson 1917.

4373 a Folkminnesuppteckningar från Arvidsjaur gjorda av E. Brännström 1931.

5585 Folkminnesuppteckningar från Arvidsjaur och Arjeplog gjorda av E. Brännström 1932.

7017 Folkminnesuppteckningar från Vilhelmina gjorda av N. Eriksson 1933-34.

\section{Published sources and literature}

Bäckman, L. 1975. Sajua. (Stockholm Studies in Comparative Religion 13.) Stockholm.

Bäckman, L. \& Hultkrantz, ̊. 1978. Studies in Lapp shamanism. (Stockholm Studies in Comparative Religion 16.) Stockholm.

Demant-Hatt, E. 1928. Offerforestillinger og erindringer om troldtrommen hos nulevende lapper. Festskrift til Rektor J. Qvigstad. (Troms $\emptyset$ museums skrifter 2.) Oslo. 
Egerbladh, O. 1969. Tärna. (Ur lappmarkens bebyggelsehistoria 8.) Umeå.

Eliade, M. 1964. Shamanism. New York.

Fellman, I. 1910. Handlingar och uppsatser angående finska lappmarken och lapparne 1. Helsingfors.

Forsslund, K.-E. 1914. Som gäst hos fjällfolket. (Lapparne och deres land 4.) Stockholm.

Grundström, H. 1946-54. Lulelapsk ordbok-Lulelappisches Wörterbuch. (Skrifter utgivna genom Landsmåls- och Folkminnesarkivet i Uppsala C, 1.) Uppsala.

Hallström, G. 1910. Traditioner om lapptrumman. Fataburen.

Hasselbrink, G. 1981-1985. Südlappisches Wörterbuch-Oårj"elsaamien baaguog'ärjaa 1-3. (Skrifter utgivna genom Dialekt- och Folkminnesarkivet i Uppsala C, 4.) Uppsala.

Högström, P. 1747. Beskrifning öfwer de til Sweriges Krona lydande Lapmarker. Stockholm.

Kildeskrifter til den Lappiske Mythologi 1. 1903. [Ed. by] J. Qvigstad. (Det Kgl. Norske Videnskabers Selskabs Skrifter 1903, 1.) Trondhjem.

Kildeskrifter til den Lappiske Mythologi 2. 1910. [Ed. by] J. Qvigstad. (Det Kgl. Norske Videnskabers Selskabs Skrifter 1910, 4.) Trondhjem.

Kolmodin, T. 1914. Folktro, seder och sägen frän Pite lappmark. (Lapparne och deras land 3.) Stockholm.

Laestadius, L. L. 1959. Fragmenter i Lappska Mythologien. [Ed. by] H. Grundström Svenska Landsmål B, 61. Stockholm.

Leem, K. 1767. Beskrivelse over Finmarkens Lapper [. . .] Kiøbenhavn.

Lindahl, E. \& Öhrling, J. 1780. Lexicon Lapponicum. Holmiae.

Lundius, N. 1905. Descriptio Lapponiae. Svenska Landsmål 17, 5. Uppsala.

Lundmark, B. 1976. Reflexioner kring Sajva. Religion och bibel 35.

- 1977. Rika-Maja och andra nåjder. Västerbotten 1. Umeå.

- 1982. Baei'vi mánno nástit. (Bothniensia occidentialis 5.) Umeå.

Manker, E. 1939. Under samma himmel. Stockholm.

- 1957. Lapparnas heliga ställen. (Acta Lapponica 13.) Uppsala.

Mebius, H. 1968. Värrō. (Skrifter utgivna av Religionshistoriska institutionen i Uppsala, Hum. fak., 5.) Uppsala.

- 1972. Sjiele. (Skrifter utgivna av Religionshistoriska institutionen i Uppsala, Hum. fak., 9.). Uppsala.

Pettersson, O. P. 1944. Gamla byar $i$ Vilhelmina 2. Stockholm.

- 1979. Kristoffer Sjulssons minnen. [Ed. by] L. Bäckman \& R. Kjellström. (Acta Lapponica 20.) Lund.

Ramselius, N. 1920. Vår nordliga hembygd. Örnsköldsvik.

Reuterskiöld, E. 1910. Källskrifter till lapparnas mytologi. 1910. (Bidrag till vår odlings häfder 10.) Stockholm.

Ruong, I. 1944. Studier i lapsk kultur i Pite lappmark och angränsande områden. Svenska Landsmål 1943-1944.

Schlachter, W. 1958. Wörterbuch des Waldlappendialekts von Malå und Texte zur Ethnographie. (Lexica Societatis Fenno-Ugricae 14.) Helsinki.

Skanke, H. 1945. Epitomes Historiae Missionis Lapponicae 1. [Ed. by] O. Solberg. Nordnorske samlinger 5. Oslo.

Svanberg, I. 1981. Sockenlappar. (Etnologiska institutionens småskriftsserie 31.) Uppsala. 